\title{
Sexually transmitted diseases Extract from the Annual Report of the Chief Medical Officer of the Department of Health and Social Security for the Year $1978^{1}$
}

The principal characteristics of the year under review have been the continued increase in new cases of nonspecific genital infection, genital candidosis, and genital herpes simplex. There has also been an increase in the number of cases of both early and late syphilis, but the incidence of gonorrhoea appears to have levelled out and there was actually a slight reduction in the number of reported cases in both sexes.

The number of new patients attending the clinics increased by $2 \%$ to 518839 . There was also a $5 \%$ increase to 96769 in the number of patients attending who were found to be healthy and noninfected, indicating that the public continues to use the services of the clinics for counselling on a wide variety of sexual problems and conditions which are not transmitted by sexual contact. The incidence of sexually transmitted diseases which are symptomless is increasing and there is some indication that people who have been at risk of infection are more inclined to attend for a check-up to allay their anxiety.

\section{Syphilis, gonorrhoea, and chancroid}

SYPHILIS

Table I shows an increase in the incidence of early syphilis of $6.4 \%(5.4 \%$ in men and $11.8 \%$ in women) but the figures for primary and secondary syphilis show little change. Late syphilis shows a $15 \cdot 8 \%$ increase overall. The rate per 100000 population is given in table II.

\section{GONORRHOEA}

Total cases of gonorrhoea showed a decrease of $2 \cdot 8 \%$ (men $2 \cdot 5 \%$; women $3 \cdot 3 \%$ ) (tables I and II). Penicillin-resistant $\beta$-lactamase-producing strains of gonococci continue to be imported into this country from West Africa and South-east Asia in small numbers. Their diffusion throughout the United Kingdom has been prevented by prompt recognition, correct treatment, energetic contact-tracing, and surveillance to ensure that a complete cure has occurred. Continuous vigilance is essential if gonorrhoea is to continue to be controlled in the United Kingdom.

\section{CHANCROID}

There was a slight increase in the number of cases in both sexes (tables I and II).

\section{Other sexually transmitted diseases}

NON-SPECIFIC GENITAL INFECTION

Cases of non-specific genital infection have increased

TABLE I Cases of syphilis, gonorrhoea and chancroid reported in England for the year ending 30 June 1978, with the revised figures for the year ending 30 June 1977 in parentheses (for the incidence rates per 100000 population see table II $†$ )

\begin{tabular}{|c|c|c|c|c|c|c|}
\hline Syphilis & \multicolumn{2}{|c|}{ Total No of cases } & \multicolumn{2}{|l|}{ Men } & \multicolumn{2}{|c|}{ Women } \\
\hline $\begin{array}{l}\text { Eypnins } \\
\text { Early } \\
\text { Primary and secondary only } \\
\text { Late } \\
\text { Congenital }\end{array}$ & $\begin{array}{r}2755 \\
1747 \\
1427 \\
155\end{array}$ & $\begin{array}{r}(2590) \\
(1733) \\
(1232) \\
(144)\end{array}$ & $\begin{array}{r}2300 \\
1499 \\
976 \\
51\end{array}$ & $\begin{array}{r}(2183) \\
(1486) \\
(828) \\
(57)\end{array}$ & $\begin{array}{l}455 \\
248 \\
451 \\
104\end{array}$ & $\begin{array}{r}(407) \\
(247) \\
(404) \\
(87)\end{array}$ \\
\hline $\begin{array}{l}\text { Gonorrhoea } \\
\text { All forms } \\
\text { Post-pubertal gonorrhoea } \\
\text { All ages } \\
\text { Under } 16 \text { years } \\
16-19 \text { years } \\
20-24 \text { years } \\
25-34 \text { years* } \\
35-44 \text { years* } \\
45 \text { years and over* }\end{array}$ & $\begin{aligned} & 57501 \\
& \\
& 57 \quad 465 \\
& 577 \\
& 11304 \\
& 19317 \\
& 18720 \\
& 5753 \\
& 1794\end{aligned}$ & $\begin{array}{r}(59155) \\
\\
(59116) \\
(568) \\
(11836) \\
(19903) \\
(19109) \\
(5872) \\
(1828)\end{array}$ & $\begin{array}{r}36266 \\
\\
36254 \\
149 \\
4558 \\
11767 \\
13589 \\
4687 \\
1504\end{array}$ & $\begin{array}{r}(37204) \\
\\
(37192) \\
(112) \\
(4782) \\
(12196) \\
(13823) \\
(4729) \\
(1550)\end{array}$ & $\begin{array}{r}21235 \\
21211 \\
428 \\
6746 \\
7550 \\
5131 \\
1066 \\
290\end{array}$ & $\begin{array}{r}(21951) \\
(21924) \\
(456) \\
(7054) \\
(7707) \\
(5286) \\
(1143) \\
(278)\end{array}$ \\
\hline Chancroid & 49 & (42) & 43 & (39) & 6 & (3) \\
\hline
\end{tabular}

*Only one group (25 years and over) was collected before 1977.

†Note: in the original report this should read, "Table $5 \cdot 3$ " and not "Table 4.3." 


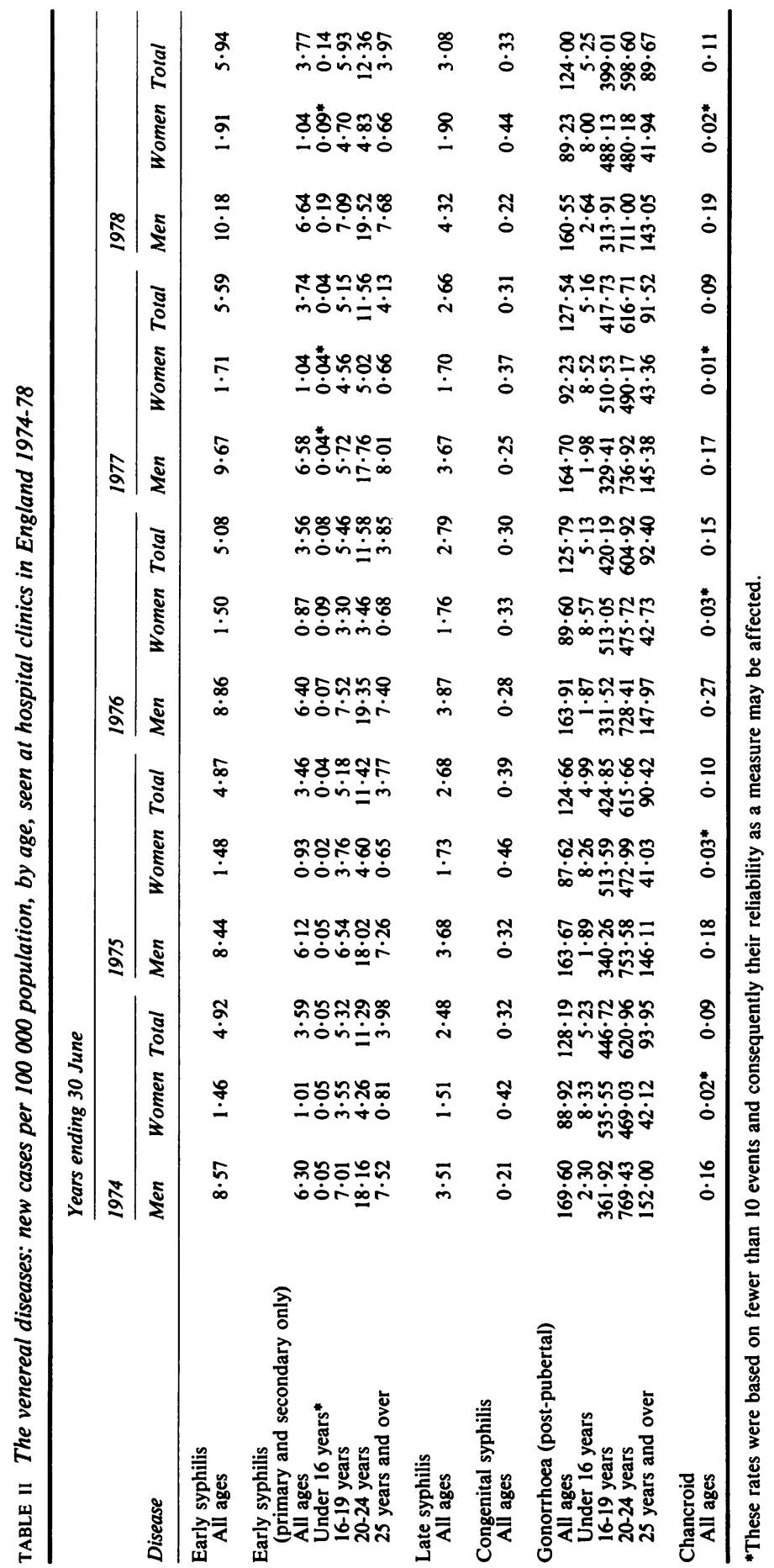



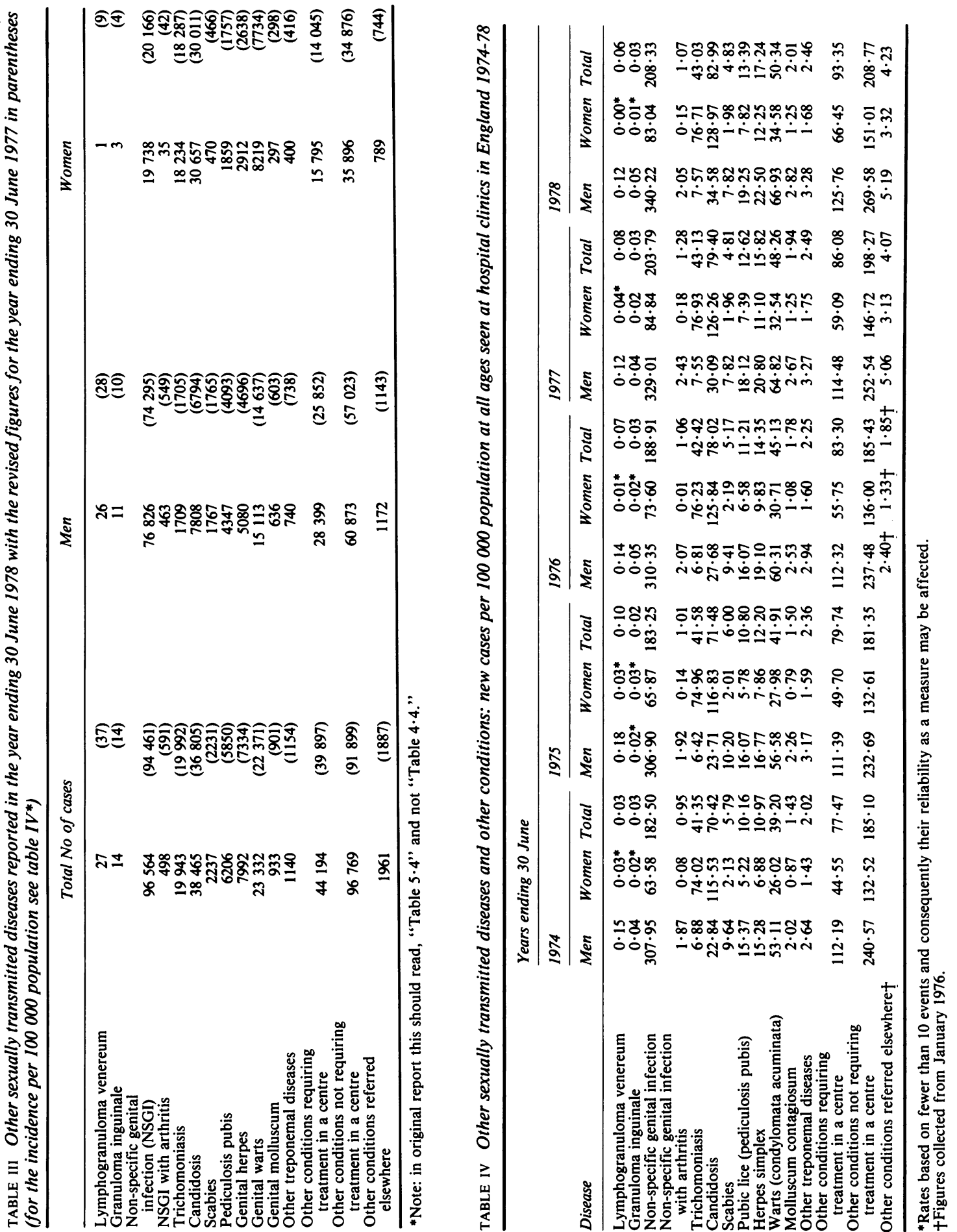
by $2 \cdot 2 \%(3 \cdot 4 \%$ increase in men; $2 \cdot 1 \%$ decrease in women) (tables III and IV).

\section{CANDIDOSIS}

Cases of candidosis have increased in both sexes, more particularly in men (14.9\% increase) (tables III and IV).

\section{GENITAL HERPES}

This has increased in both sexes (tables III and IV).

\section{Contact-tracing}

Considerable progress continues to be made in contact-tracing and more workers and improved facilities are now available in clinics throughout the country. The Society of Social Health Workers in Venereology is now well established and holds an annual conference in a major centre in the United Kingdom. The last meeting was held in Liverpool and was well attended. Efforts are continuing to provide training opportunities for this group of workers.

\section{Staffing}

The number of hospital medical staff engaged in genitourinary medicine in England and Wales at $\mathbf{3 0}$ September 1978 totalled 203 (185 whole-time equivalents (wte) compared with 211 (188.6 wte) on 30 September 1977). The 1978 figures included 101 $(95 \cdot 1$ wte) consultants, $36(33 \cdot 7)$ senior registrars, and $35(33 \cdot 5)$ registrars compared with 106 (99 wte) consultants, 35 (32.6 wte) senior registrars, and 32 $(30 \cdot 2$ wte) registrars at 30 September 1977 . At 30 September 1978, in addition to the above, there were 17 (4.8 wte) hospital practitioners and 144 (33.3 wte) staff holding sessional appointments under paragraph 94 of the Terms and Conditions of Service.

The Specialist Advisory Committee in Genitourinary Medicine of the Royal College of Physicians recommends that applicants for consultant posts should possess a suitable higher qualification-usually the Membership of the Royal College of Physicians-and have completed four years of specialist training at senior registrar level. Because recruitment in the specialty still causes problems in some areas of the country, the Specialist Advisory Committee may sometimes give accreditation to trainees from other branches of medicine whose previous experience has been carefully assessed and found to be acceptable.
Recruitment of suitable male nurses has been inadequate in recent years and retirements have left some important posts unfilled. It is hoped that the highly successful post-registration courses organised by the Joint Board of Clinical Nursing Studies will help to solve this problem by attracting younger nurses to the specialty.

\section{Education and training}

The first professor of genitourinary medicine in the world, Professor Michael Adler, occupied the chair created at the Middlesex Hospital Medical School of London University on 1 January 1979 and is now establishing the academic department.

The 29th General Assembly of the International Union against the Venereal Diseases and Treponematoses took place in Leeds in May 1978. There were over 200 delegates from 25 different countries in all parts of the world. Dr R D Catterall, consultant adviser in genitourinary medicine to the DHSS, was elected President of the International Union for the next five years.

Several international meetings were held in 1978, including an expert committee of the World Health Organisation in Geneva on the newer sexually transmitted diseases. Other conferences took place in Zurich, Vienna, New Delhi, Paris, Perth (Western Australia), and San Francisco. British physicians took part and contributed papers at all these meetings.

The DHSS continues to make available a sum of money for workers in the field to visit centres overseas to learn new techniques and to study special aspects of the subject. These grants have been of great value in enabling British doctors, nurses, contact-tracers, and social workers to study disease control overseas.

Health education about the sexually transmitted diseases requires further development in the United Kingdom. Because of the continuing high prevalence of most of these diseases, further developments in this aspect of the subject are desirable, both at local and national levels.

\section{Reference}

1. Department of Health and Social Security. Sexually transmitted diseases. On the State of the Public Health: The Annual Report of the Chief Medical Officer of the Department of Health and Social Security for the Year 1978. London: HMSO. 1979:60-65. 